Tourism 2014, 24/1

\author{
Leszek Butowski \\ Warsaw School of Tourism and Hospitality Management \\ leszek.butowski@wp.pl
}

\title{
MARITIME TOURISM SPACE
}

\begin{abstract}
The aim of this article is to provide a description of the processes which take place within offshore and coastal areas treated as contemporary tourism space. The article presents the evolution of maritime space towards the formation of maritime tourism space. It also offers a classification of maritime tourism space types according to types of sailing tourism (investigated on a global scale). The analysis has covered the main geographical-structural conditions and forms of adaptation (with particular focus on coastal areas). The analysis covered seaside areas as well, but only in the context of their functional relation with sea areas. The entire investigation was conducted from the perspective of maritime sailing tourism (yachts and other recreational crafts).
\end{abstract}

Keywords: maritime tourism space; evolution, stages of adaptation; sailing tourism.

\section{INTRODUCTION}

This article offers an analysis of maritime areas and areas directly adjacent to them as areas of contemporary tourism space. The term 'tourism space' is used here in the sense of a real geographical space which receives tourists and which has a certain functional and behavioural character ( $c f$. DRZEWIECKI 1992' KOWALCZYK 2001, MIOSSEC 1977, STACHOWSKI 1993, STALSKI 1984, WARSZYŃSKA \& JACKOWSKI 1978). According to S. LISZEWSKI (1995) and B. W€ODARCZYK (2009) an area can be considered a tourism space only when it is visited by tourists (regardless of their number). Obviously, this condition has been fulfilled by many sea areas; therefore, we have to recognize them (and seaside areas which are functionally tied to them) as tourism space.

Taking these assumptions into account, let us assume for the length of this article that maritime tourism space is a real geographical space which is visited by tourists because of certain sea-related attractions that it pocesses. It may encompass sea areas and the land areas that are functionally bound to them. This space (especially land and coastal areas) can be deeply transformed and adapted to fulfil the needs of tourists.

The article focuses mainly on: 1) conditions which influence the formation of maritime tourism space; 2) evolution of maritime space towards maritime tourism space; 3) distinguishable types of maritime tourism space; 4) forms of adaptation to the needs of sailing tourism. As mentioned before, the analysis covers also seaside areas, but only in the context of their functional ties to particular sea areas. The analysis is conducted from the perspective of sea sailing tourism (yachts and other recreational crafts) disregarding other forms of nautical tourism (e.g. cruising), which have already been described in numerous literary sources ( $c f$. LUKOVIĆ 2012, LUKOVIĆ 2013, LÜCK 2007, LÜCK 2008).

\section{CONDITIONS INFLUENCING THE FORMATION OF MARITIME TOURISM SPACE}

When we look at the structure of maritime tourism space, we see that it can be divided into two basic constituents (which in the context of sailing tourism are functionally tied to each other): sea area and the seaside area that is directly adjacent to it. The main conditions (factors) which have an influence on the formation of maritime tourism space (encompassing both constituents) are:

1. Geographical location and resulting dominance of certain weather conditions which influence prospects for the development of sailing tourism in a given area. These weather conditions include (dominant) wind direction and strength, frequency of 
occurrence of strong winds and storms, occurrence of gales, likeliness of sudden weather changes.

2. Topographical conditions (type of coastline), including in particular the presence of islands, peninsulas, bays, fiords, straits, etc. which influence conditions for sailing tourism. They may constitute natural shelters, for example for yachts, especially during bad weather.

3. Hydrographical conditions, such as depth, presence of dangerous shoals, height and type of waves, occurrence of wind currents, tidal streams and tides (vertical fluctuations of the level of water). These factors have an influence mainly on the safety of sailing on small vessels.

4. The sightseeing and recreational attractiveness of sea and seaside areas is determined by for instance 'traditional' sightseeing attractions (e.g. occurrence of particular species of fauna and flora, sailing and nautical traditions). Moreover, the formation of maritime tourism space can be influenced by other typical enrivonmental attractions, such as water quality, transparency and temperature, and air temperature in a given season of the year, the number of sunny and rainy days, likeliness of fair weather, etc.

5. Specific sailing and nautical attractions of the sea - apart from the above-mentioned structural factors - include the formation of certain types of maritime tourism space and depend on some more subjective sailing and nautical conditions characterising a given sea area. These attractions depend on the peculiar 'sailing needs' of different groups of sailing tourists. Due to this the same area may be seen by different groups of tourists as more or less attractive. Two European water areas can be used as examples of such diverse evaluations namely: the Dalmatian Coast in Croatia and the waters of Northern Scotland. The former is considered a paradise for those seeking calm, easy and safe sailing in good weather conditions and nights spent in harbours and marinas. On the other hand, the waters of Croatia are much less appealing to those who seek a sailing challenge. They will prefer the archipelagos of Northern Scotland (the Shetland Islands, the Orkneys or the Hebrides) where navigation is much more challenging and where even in summer unfavourable hydrometeorological conditions are not uncommon.

6. The adaptation of sea areas to the needs of sailing tourism is connected primarily with sailing safety and the fulfilment of basic provisional needs of sailors. A more detailed description of various forms of maritime tourism space adaptation is included in a separate part of the article.

7. Accessibility of a sea area is largely determined by its geographical location. It is much more difficult to ensure access to areas which are located peripherically (in particular islands) in relation to the main countries and/or regions from which sailing tourists come. The problem can be solved relatively easily in regions of high tourism potential, e.g. Balearic Islands or the Canary Islands, by setting up special flight connections. It can be, however, a serious obstacle for other regions which are equally attractive but have smaller potential, e.g. Malta, or which are located peripherically in relation to main source markets (e.g. South Pacific, Seychelles, Cape Verde Islands).

8. Location of a maritime tourism space in relation to other sea areas used by sailors - this criterion allows an assessment of a given area in the context of its relation to other areas used by sailing tourism; in this way it can be determined whether a given sea area is considered by sailing tourism a destination area or just an intermediate area (passage). Two (or more) neighbouring sea areas can attract more sailing tourists than either of them would on its own, e.g. Swedish South East coast (near Stockholm) and the Alland Islands, Scottish sea areas around the Shetland Islands, the Orkneys and the Hebrides.

9. Competition from other regions - an important factor which influences the possibility of the formation of a maritime tourism space - is the location of the area in question in relation to other areas with a developed function for providing services for sailing tourism. Various features can be taken into account, e.g. physical-geographical conditions, accessibility, prices and others.

Table 1. Factors influencing maritime tourism space and criteria for the evaluation of the needs of sailing tourism

\begin{tabular}{|c|c|c|}
\hline \multirow{2}{*}{$\begin{array}{l}\text { Criteria for } \\
\text { the evaluation } \\
\text { of maritime } \\
\text { tourism space }\end{array}$} & \multicolumn{2}{|c|}{$\begin{array}{l}\text { Factors influencing the formation of maritime } \\
\text { tourism space }\end{array}$} \\
\hline & anthropogenic & natural \\
\hline \multirow{3}{*}{$\begin{array}{l}\text { Sailing safety; } \\
\text { Sailing and } \\
\text { nautical } \\
\text { attractions of sea } \\
\text { areas }\end{array}$} & $\begin{array}{l}\text { - sheltered harbours } \\
\text { for sailing yachts }\end{array}$ & $\begin{array}{l}\text { Natural (topo- } \\
\text { graphical) condi- } \\
\text { tions in waterfront } \\
\text { zone influencing the } \\
\text { opportunity to build } \\
\text { yachts, harbours } \\
\text { and marinas }\end{array}$ \\
\hline & $\begin{array}{l}\text { - } \text { navigational signs; } \\
\text { - } \text { search and rescue } \\
\text { systems, naviga- } \\
\text { tional warnings and } \\
\text { weather forecasts; } \\
\text { - } \text { specialist sailing } \\
\text { publications (charts, } \\
\text { pilot books) }\end{array}$ & \multirow{2}{*}{$\begin{array}{l}\text { Natural conditions } \\
\text { in sea area, } \\
\text { including climatic- } \\
\text { weather and } \\
\text { hydrographical } \\
\text { conditions } \\
\text { influencing sailing } \\
\text { safety and sailing } \\
\text { attractiveness } \\
\text { (nautical values) }\end{array}$} \\
\hline & $\begin{array}{l}\text { - use of a sea area by } \\
\text { other vessels; } \\
\text { - organization of } \\
\text { traffic in a sea area; } \\
\text { - presence of } \\
\text { restricted areas and } \\
\text { navigational } \\
\text { obstacles }\end{array}$ & \\
\hline
\end{tabular}




\begin{tabular}{|c|c|c|}
\hline \multirow{2}{*}{$\begin{array}{l}\text { Criteria for } \\
\text { the evaluation } \\
\text { of maritime } \\
\text { tourism space }\end{array}$} & \multicolumn{2}{|c|}{$\begin{array}{l}\text { Factors influencing the formation of maritime } \\
\text { tourism space }\end{array}$} \\
\hline & anthropogenic & natural \\
\hline $\begin{array}{l}\text { Sightseeing and } \\
\text { recreational } \\
\text { attractiveness } \\
\text { of the sea area } \\
\text { and seaside area }\end{array}$ & $\begin{array}{l}\text { - presence, rank and } \\
\text { management of } \\
\text { anthropogenic } \\
\text { attractions; } \\
\text { - adaptation of } \\
\text { natural attractions }\end{array}$ & $\begin{array}{l}\text { Presence and rank } \\
\text { of natural environ- } \\
\text { ment attractions }\end{array}$ \\
\hline \multirow{6}{*}{$\begin{array}{l}\text { Adaptation of sea } \\
\text { area and seaside } \\
\text { area to the needs } \\
\text { of sailing tourism }\end{array}$} & $\begin{array}{l}\text { - functioning of } \\
\text { marinas, harbours } \\
\text { and other places of } \\
\text { mooring }\end{array}$ & $\begin{array}{l}\text { Natural conditions } \\
\text { influencing the } \\
\text { possibility of creat- } \\
\text { ing a coastal infra- } \\
\text { structure (bays, } \\
\text { fiords, peninsulas, } \\
\text { river mouths, } \\
\text { others) }\end{array}$ \\
\hline & $\begin{array}{l}\text { - national and local } \\
\text { regulations concern- } \\
\text { ing sailing in a given } \\
\text { sea area } \\
\end{array}$ & \\
\hline & - yacht charter offer & \\
\hline & $\begin{array}{l}\text { - level of prices of } \\
\text { sailing and other } \\
\text { basic services in } \\
\text { marinas and } \\
\text { harbours; } \\
\text { - prices and } \\
\text { availability of yacht } \\
\text { charter } \\
\end{array}$ & \\
\hline & $\begin{array}{l}\text { - promotion of the } \\
\text { sailing tourism } \\
\text { qualities of a region }\end{array}$ & \\
\hline & $\begin{array}{l}\text { - attitude of local } \\
\text { communities } \\
\text { towards tourism }\end{array}$ & \\
\hline $\begin{array}{l}\text { Geographical } \\
\text { location of sea } \\
\text { area and seaside } \\
\text { area }\end{array}$ & & $\begin{array}{l}\text { Geographical } \\
\text { location of a given } \\
\text { sea area in relation } \\
\text { to other sea areas } \\
\text { used by sailors }\end{array}$ \\
\hline $\begin{array}{l}\text { Accessibility } \\
\text { of sea area and } \\
\text { seaside area }\end{array}$ & $\begin{array}{l}\text { Organization of } \\
\text { passenger transport } \\
\text { determining } \\
\text { accessibility of given } \\
\text { sea area }\end{array}$ & $\begin{array}{l}\text { Distance from } \\
\text { source markets and } \\
\text { accessibility to } \\
\text { sailors from these } \\
\text { markets }\end{array}$ \\
\hline $\begin{array}{l}\text { Competition from } \\
\text { other water areas }\end{array}$ & $\begin{array}{l}\text { Marketing activities } \\
\text { promoting sea area as } \\
\text { attractive for sailors }\end{array}$ & $\begin{array}{l}\text { Presence of compet- } \\
\text { ing sea areas }\end{array}$ \\
\hline
\end{tabular}

Source: personal findings based on BUTOWSKI (2010, p. 110).

\section{EVOLUTION OF MARITIME SPACE TOWARDS THE FORMATION OF MARITIME TOURISM SPACE}

When speaking about the development of the function of sea sailing tourism in relation to sea and seaside areas in which it is realised two main (in the genetic sense) stages of evolution can be distinguished: 1) sailing tourism as a primary function in a given area; 2) sailing tourism as a secondary function which replaces other functions present in a given area.
Sailing tourism as a primary function is usually developed on a so-called 'raw root', i.e. areas which have not been previously used by tourism and which do not currently have any other economic function. Introducing the new function of sailing tourism services to such areas is usually a result of deliberate spatial planning and following investment. In practice it can be realised on a small or on a large scale. In the first case it involves building (often spatially isolated) elements of sailing infrastructure in areas which at present do not have any economic function (e.g. building yacht harbours in Łeba and Puck). The second type involves managing larger areas (which have not previously had any significant economic function) by supplying them with a network of functionally tied objects and facilities to provide services for sailing tourism. An example of an activity on a large scale is the Dalmatian Coast of Croatia, where a network of ACI marinas providing services for sailing tourism was mostly created on previously unused land (e.g. Kornati National Park).

Sailing tourism as a secondary function involves replacing other functions in a given area. In recent decades, the economic functions of many areas (in particular some sea areas) are changing. Changes of this type can be clearly seen on European waters where previous functions (mainly fishery) have been to a large extent replaced by new types of activity, in particular sailing tourism (KULIŃSKI 2002, 2007, 2008, 2009). Such changes have occurred in Poland (e.g. Puck, Jastarnia, Gdańsk - Górki Zachodnie, Kołobrzeg, Darłowo, Władysławowo), Denmark, France, Germany and Sweden. Wide-scale transformation of former fishing ports into marinas and yacht harbours in these countries confirms this general tendency.

An interesting situation can be seen on oceanic waters (intercontinental routes), where after the twilight of passenger ships sea yacht sailors have become the most numerous and in practice the only tourism users of these sea areas. In this sense, sea sailing tourism on oceanic waters is secondary in relation to previous forms of usage.

\section{TYPES OF MARITIME TOURISM SPACE}

From the perspective of sailing tourism, maritime tourism space (with connected seaside areas) can be divided into groups based on various criteria, such as distance from the coast, number of sailors, intensity and ways of adaptation. According to these criteria the following types of maritime tourism space can be distinguished:

1. Seaside tourism space (functionally connected with sailing tourism services): contains dwellings and 
other parts of a settlement functionally tied to sailing tourism (accommodation in marinas, holiday homes, suites, condominiums near yacht harbours). Tourism space of this type often overlaps with space used by other types of seaside tourism and other non-tourism functions. In the genetic sense seaside tourism space can be either primary or secondary.

2. Waterfront tourism space: characterised by a concentration of various forms of sailing tourism infrastructure and services (marinas, yacht harbours, other accompanying services, e.g. yacht charters, boatbuilders, etc.). Tourism space of this type often overlaps with space used by other types of seaside tourism and other economic functions. In the genetic sense waterfront tourism space can be either primary or secondary.

3. Coastal tourism space (inshore): encompasses sea areas located in the vicinity of land (by convention up to 20 nautical miles from the coastline). It is intensely used by sailors and other 'tourism' and 'nontourism' users (including ferry lines, cruising ships, fishing boats, cargo ships, naval ships).

4. Offshore tourism space: this constitutes an extension of the coastal zone towards open sea. It encompasses offshore sea areas (by convention up to 150 nautical miles from the coastline or shelter) which are used mainly by sailors and to a lesser extent by other users (ferry lines, cruising ships, fishery, cargo ships, naval ships).

5. Ocean tourism space: encompasses ocean areas (intercontinental), apart from sailors used also by cargo ships and deep sea fisheries. In terms of surface area, it constitutes the biggest part of maritime tourism space, but in practice it encompasses mainly certain characteristic parts of the oceans where conditions for sailing are favourable e.g. trade winds routes.

\section{ADAPTATION OF MARITIME SPACE TO SAILING TOURISM}

Maritime space is adapted to sailing tourism in order to fulfil all the functions that are typically ascribed to tourism infrastructure of a given area ( $c f$. KOWALCZYK \& DEREK 2010, ROGALEWSKI 1979, STYPEREK 2002). Tourism adaptation enables fulfilling the specific needs of sailors, in particular those connected with sailing safety (especially regarding small recreational vessels); at the same time it facilitates a specific perception of sea and land tourism attractions, promotes the preservation of tourism resources in a given area and allows for commercialization of these attractions. Moreover, adaptation of maritime space by sailing tourism contributes to an improvement of internal and external accessibility. It is beyond doubt that particular structural elements of adaptation shape tourism space, in this case maritime space, both in terms of structure and function.

Elements of adaptation of maritime space which have an influence on the safety of sailing on small vessels are shelters (harbours; important are location and accessibility during bad weather); navigational signs, operating search and rescue systems, availability of weather forecasts and warnings, navigational warnings, availability of specialist sailing publications (charts, pilot books, guide books for sailors); organization of traffic on a given sea area (traffic regulations, coastal sailing zones).

The remaining needs of sailors as well as the perception and preservation of sea and land tourism attractions are realised by such adaptation as marinas, harbours and other places of mooring for small recreational crafts; specific sailing services; yacht charter offer; minimalization of barriers caused by national and local regulations concerning sailing on a given sea area (also for foreign sailors); marine and terrestrial national parks and other forms of preservation and promotion of natural resources. The perception of specific sailing attractions is ensured by the abovementioned elements of adaptation connected with sailing safety. Commercialization of the sailing tourism resources of a given area is possible thanks to the services offered by marinas and harbours - services that are necessary for sailing tourism, e.g. yacht charter, shops selling specialist equipment, food, navigational instruments, boatbuilding services.

When analysing the intensity of the adaptation of maritime tourism space in relation to distance from coastline we may observe that the farther away from the coastline the less intense the adaptation. This rule is general and valid regardless of the real level of adaptation of a given space (Fig. 1).

Moreover, by applying this model and using per analogiam S. LISZEWSKI's (1995) conception concerning stages of the formation of tourism space, we can distinguish zones of maritime tourism space. For the sake of simplicity, the names of the zones have been borrowed from Liszewski without change and they are ascribed to the previously distinguished types of maritime tourism space. Thus, particular zones are as follows:

- exploration zone - corresponds to physical oceanic space; it does not contain any material elements of adaptation to sailing tourism. The intensity of sailing tourism is lowest (as a consequence of the size of the zone and distance from land).

- penetration zone - is located offshore, it (as a rule) does not have any material elements of adaptation to sailing tourism, although sporadically it may contain certain elements 


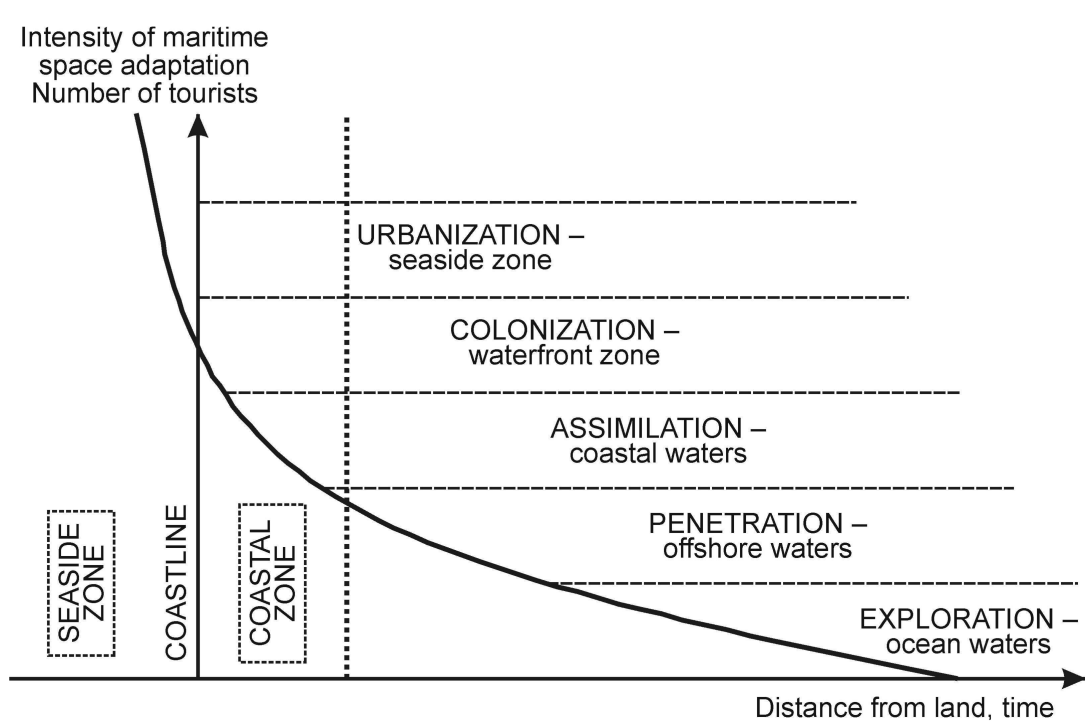

Fig. 1. Intensity of adaptation of maritime tourism space and number of tourists as a function of time and distance from coastline Source: personal findings

- connected with sailing safety. The intensity of sailing tourism is low (the zone is vast and the distance from coastline is large).

- assimilation zone - encompasses coastal waters; because sailing tourism is intense within this zone, there are numerous and various forms of adaptation, which concern mainly sailing safety and protection of water and land.

- colonization zone - refers to water and land areas located directly at the coastline. In this zone numerous facilities which enable sailing tourism, such as marinas, harbours and accompanying services are located.

- urbanization zone - refers to land areas; it is characterized by the presence of dwellings and tourism accommodation in the immediate vicinity of marinas and ports (or even constituting an integral part of them). It is important to note that these dwellings appeared because of the functioning of the afore-mentioned sailing infrastructure ${ }^{1}$.

It must be mentioned, however, that despite similarities to the model of S. Liszewski, maritime tourism space has different origins. In the process of the formation of maritime tourism space the first stages, in the chronological sense, are colonization and urbanization. As described earlier, both stages occur on areas (seaside and land respectively) which are located in the immediate vicinity of a coastline. At the same time they constitute the first stage of the transformation of maritime (sea and land) tourism zone the first condition which needs to be fulfilled for other stages (concerning sea areas only), i.e. assimilation, penetration and exploration ${ }^{2}$ to appear. As we can see, the process is different from S. Liszewski's model of the transformation of tourism space, where the order of stages is reversed, from exploration to colonization.

It seems that this reverse order may be explained by the following premises: 1) the transformation of space towards tourism space is often in chronological terms, secondary, i.e. it concerns space which has been previously colonized and urbanized by other types of activity (functions), e.g. by a fishery; 2) if sailing tourism is to operate on a larger scale, it needs a base on land, therefore land needs to be properly adapted for the new functions, which means colonization and often urbanization; 3) the specific character of maritime space, in particular offshore and ocean, prevents stages other than exploration and penetration from occurring; exploration and penetration should be considered in this case secondary in relation to earlier stages (assimilation, colonization, urbanization) which appear on coastal waters and areas in the immediate vicinity of coastline.

A specific form of adaptation of maritime tourism space to sailing tourism, which concerns oceanic and offshore waters too, is the publishing of specialist charts, nautical publications, guidebooks and pilot books for sailors. In Europe, for example, the biggest number of such publications is offered by British publishers (Imray, Adlard Coles Nautical); their publications cover not only the waters of Great Britain and Ireland, but also other sea areas which are often visited by sailors ${ }^{3}$. Publications covering selected sea areas (Baltic, North Sea, the Mediterranean) by the German publishing house Delius Klassing are also 
popular. These publications, depending on what areas they cover, employ various divisions which are based mainly on geographical and nautical criteria.

Table 2. Division of sea areas in selected pilot books covering European waters

\begin{tabular}{|c|c|}
\hline $\begin{array}{l}\text { Pilot } \\
\text { book }\end{array}$ & Sea areas \\
\hline $\begin{array}{l}\text { Greek } \\
\text { Waters } \\
\text { Pilot }\end{array}$ & $\begin{array}{l}\text { Northern Ionian. Corfu to Zàkintos, Southern Ionian. } \\
\text { Killini to Kithera, Gulf of Patras and the Gulf of } \\
\text { Corinth, Saronic and Eastern Peloponnisos, } \\
\text { Cyclades, Evia and the Northern Sporades, Northern } \\
\text { Greece, Eastern Sporades, Dodecanese, Crete }\end{array}$ \\
\hline $\begin{array}{l}\text { Adriatic } \\
\text { Pilot }\end{array}$ & $\begin{array}{l}\text { Albania, Montenegro: Ulcinj to Boka Kotorska, } \\
\text { Croatia: Molunat to Podgora, Croatia: Tucepi to } \\
\text { Tribunj, Croatia: Murter to Rab, Croatia: Senj to the } \\
\text { border with Slovenia, Slovenia, Italy: from Slovenia } \\
\text { to Ancona, Italy: Numana to Manfredonia, Italy: } \\
\text { Barletta to Santa Maria di Leuca }\end{array}$ \\
\hline $\begin{array}{l}\text { Corsica } \\
\text { and North } \\
\text { Sardinia }\end{array}$ & $\begin{array}{l}\text { Bastia to Saint Florent, Saint Florent to Calvi, Calvi } \\
\text { to Cargese, Cargese to Ajaccio, Ajaccio to Propriano, } \\
\text { Propriano to Bonifacio, Bonifacio to Porto Vecchio, } \\
\text { Porto Vecchio to Bastia, Alghero to Porto Torres, } \\
\text { Porto Torres to Capo Testa, Capo Testa to Porto } \\
\text { Cervo, Porto Cervo to Olbia, Olbia to Capo Comino }\end{array}$ \\
\hline $\begin{array}{l}\text { Italian } \\
\text { Waters } \\
\text { Pilot }\end{array}$ & $\begin{array}{l}\text { Ligurian Coast, Tuscan Islands and adjacent } \\
\text { mainland coast, Tyrrhenian Sea, Sardinia, Sicily, } \\
\text { Ionian, Southern Adriatic, Malta }\end{array}$ \\
\hline $\begin{array}{l}\text { Cruising } \\
\text { Guide to } \\
\text { Germany } \\
\text { and } \\
\text { Denmark }\end{array}$ & $\begin{array}{l}\text { German Bight, German Frisian coast and the Elbe, } \\
\text { Scheswig-Holstein and Jutland west coast, Nord- } \\
\text { Ostsee Kanal and the Eider river, Jutland east coast } \\
\text { and Lille Bælt, Limfjord, South Fyn and Store Bælt, } \\
\text { South Sjaelland and the Sound, Germanic Baltic } \\
\text { coast and Bornholm (Denmark) }\end{array}$ \\
\hline $\begin{array}{l}\text { North Sea } \\
\text { Passage } \\
\text { Pilot }\end{array}$ & $\begin{array}{l}\text { Cromer to Orfordness, Orfordness to the Naze, the } \\
\text { Naze to Foulness, Thames Estuary, Straits of Dover, } \\
\text { French and Belgian coast, Schelde delta, Noord and } \\
\text { Zuid Holland }\end{array}$ \\
\hline
\end{tabular}

Source: personal findings.

Another 'virtual' form of the adaptation of offshore and oceanic waters to the needs of sailing tourism are weather forecasts and the navigational warnings broadcast for particular sea areas by radio, including for instance NAVTEX system, and by search and rescue systems using satellites.

\section{FOOTNOTES}

1. According to a definition by B. MAZURKIEWICZ (2004) a marina is a yacht harbour together with complementary settlement which includes hotels and suites, shops, bars, cafeterias, restaurants and all other functions that are required by temporary and permanent inhabitants; a yacht harbour is a complex of mooring berths, hydrotechnical port buildings, land buildings and technical units which provide a safe stay and service for recreational vessels; other places for mooring such as mooring berths (and anchorages) for recreational vessels which provide basic services for sailors.
2. In some areas, in particular those which are protected because of natural resources, the entire process consists of four stages: rudimentary colonization, assimilation, penetration and exploration. The stage of urbanization is not permitted. This is the case with for instance the Galápagos Islands or the Kornati in Croatia.

3. Among several dozen British publications cover-ing European sea areas diverse in terms of location and size are: Reeds Nautical Almanac, Shetland Islands Pilot, South and West Coasts of Ireland, The Yachtsmans Pilot to North and East Scotland, The Channel Islands, North Sea Passage Pilot, Cruising Guide to the Netherlands, Cruising Guide to Germany and Denmark, Atlantic Spain and Portugal, Mediterranean Cruising Handbook, Corsica and North Sardinia, Italian Waters Pilot, Adriatic Pilot, Greek Waters Pilot.

\section{BIBLIOGRAPHY}

Atlantic Spain and Portugal, 2006, RCC Pilotage Foundation, Imray, Cambridgeshire, England.

BESTÄNDIG K.H., 2008, Chorwacja, Stowenia, Czarnogóra. 808 portów i zatok. Przewodnik żeglarski po Adriatyku, Wyd. Mysliński, Warszawa.

BRANDON R., MARCHMENT J., 2007, Corsica and North Sardinia, Imray, Cambridgeshire, England.

BUCHANAN G., 2009, Shetland Islands Pilot, Imray, Cambridgeshire, England.

BUTOWSKI L., 2010, Morska turystyka żeglarska w Europie podstawy metodologiczne analizy jakościowej wybranych elementów popytu i podaży, Folia Turistica, 23, pp. 95-114.

BUTTRES R., DU PORT A., 2009, Reeds Nautical Almanac 2010. Atlantic Europe from the tip of Denmark to Gibraltar, Adlard Coles Nautical.

DRZEWIECKI M., 1992, Wiejska przestrzeń rekreacyjna, Instytut Turystyki, Warszawa.

HEATH N., 2006, The Channel Islands, Imray, Cambridgeshire, England.

HeIKELl R., 1998, Mediterranean Cruising Handbook, Imray, Cambridgeshire, England.

HeIKELL R., 2006, Italian Waters Pilot, Imray, Cambridgeshire, England.

HeIKELL R., 2007, Greek Waters Pilot, Imray, Cambridgeshire, England.

KOWALCZYK A., 2001, Geografia turyzmu, PWN, Warszawa.

KOWALCZYK A., DEREK M., 2010, Zagospodarowanie turystyczne, Wyd. Naukowe PWN, Warszawa.

KULIŃSKI J., 2002, Wybrane porty Bałtyku - przewodnik dla żeglarzy, Wyd. Nowator, Kartuzy.

KULIŃSKI J., 2007, Porty potudniowej Szwecji - przewodnik dla żeglarzy, Wyd. Nowator, Kartuzy.

KULIŃSKI J., 2008, Porty Niemiec Wschodnich - przewodnik dla żeglarzy, Wyd. Nowator, Kartuzy.

KULIŃSKI J., 2009, Bornholm i Christiansø - przewodnik dla żeglarzy, Wyd. Nowator, Kartuzy.

LAWRENCE M., 2002, The Yachtsmans Pilot to North and East Scotland, Imray, Cambridgeshire, England.

LISZEWSKI S., 1995, Przestrzeń turystyczna, Turyzm, 5, 2, pp. 87-103.

LUKOVIĆ T., 2012, Nautical Tourism and its Functions in the Economic Development in Europe, [in:] M. Kasimoglu (ed.), Visions for Global Tourism Industry - Creating and Sustaining Competitive Strategies, In Tech, Rijeka, pp. 399-430.

LuKOVIĆ T., 2013, Nautical Tourism, CABI, Oxfordshire (UK) Cambridge (USA). 
LÜCK M. (ed.), 2007, Nautical tourism. Concepts and issues, Cognizant Communication Corporation, New York.

LÜCK M. (ed.), 2008, The Encyclopedia of Tourism and Recreation in Marine Environments, CABI, Oxfordshire (UK) - Cambridge (USA).

MAZURKIEWICZ B., 2004, Porty jachtowe - mariny. Projektowanie, Fundacja Promocji Przemysłu Okrętowego i Gospodarki Morskiej, Gdańsk.

MiosseC J,M, 1977, Un modele de l'espace touristique, L'Espace Géographique, 6, 1, pp. 41-48.

NAVIN B., 2004, Cruising Guide to the Netherlands, Imray, Cambridgeshire, England.

NAVIN B., 2012, Cruising Guide to Germany and Denmark, Imray, Cambridgeshire, England.

NAvin B., 2013, North Sea Passage Pilot, Imray, Cambridgeshire, England.

ROGALEWSKI O., 1979, Zagospodarowanie turystyczne, WSiP, Warszawa.
South and West Coasts of Ireland, 2006. Sailing Directions, Irish Cruising Club.

STACHOWSKI J., 1993, O pojmowaniu przestrzeni w geografii turyzmu, Acta Universitatis Nicolai Copernici. Geografia, 24, Nauki Matematyczno-Przyrodnicze, 82, pp. 171-180.

STALSKI M., 1984, Użytkowanie ziemi w turystyce, [in:] M. Stalski (ed.), Turystyka i rekreacja, Przeglad Zagranicznej Literatury Geograficznej, 2, pp. 139-148.

STYPEREK J., 2002, Linearne systemy penetracji rekreacyjnej, Wyd. Naukowe Bogucki, Poznań.

THOMPSON T., THOMPSON D., 2011, Adriatic Pilot. Croatia, Slovenia, Montenegro, East Coast of Italy, Albania, Imray, Cambridgeshire, England.

WARSZYŃSKA J., JACKOWSKI A., 1978, Podstawy geografii turyzmu, PWN, Warszawa.

WŁODARCZYK B., 2009, Przestrzeń turystyczna. Istota, koncepcje, determinanty rozwoju, Wyd. Uniwersytetu Łódzkiego, Łódź. 